very often acquired, or cleveloped, rather late in life, after the victims of them have produced all their children. The children cannot in such cases inherit any of the effects of such habits on the constitution. It is the general experience of breeders of animals that the offspring inherit characters more strongly when the parents are more mature, that is to say, characters which continne to develop until an advanced period of life, e.g., the peculiarities of the carrier pigeon. The mental powers in man are an example of the same kind They continue to develop long after the time at which most men beget their children, and there is some reason to believe that younger sons generally inherit more brain-power as well as less property. There is also some reason to believe that children produced of aged parents are, in a sense, born old. Such facts, if they are facts, cannot be explained on the assumption that the germ-cells are independent of the history of the soma, and in investigating the inheritance of degeneration due to alcoholism the duration of the alcoholism in the parents before the generation of the children must be ascertained.

June 21st, 1901. I am, Sirs, yours faithfully,

J. T. CUNNINGHAM.

\section{To the Editors of THE LANCET}

SIRs,-To judge by Dr. Andrew Wilson's letter in THE LANCET of June 29th, p. 1861, I do not seem to have made my position as "clear" as he asserts. I am sure I do not know whether "the germ-plasm is utterly independent of the body-plasm," or "whether the great divergence between germ and soma contended for by Galton (?) and Weismann is a reality." I know absolutely nothing about all that, and. notwithstanding the vast flood of mystical chatter indulged in by various eminent biologists, I am equally sure that noborly else knows more. But I do positively know (1) that a child (for instance) is derived from a single cell of each parent and (2) that the soma (i.e., the other cells) of each man acquires millions of traits. It seems to me incredible that each of these millions of acquirements can so affect the germ that erery particular acquirement tends to be reproduced by the child. In other words, the assumption that the offspring of the germ cell tend to reproduce the acquirements of the other cells seems to me as improbable as the assumption that the offspring of Brown tend to reproduce the acquirements of Jones and Robinson. I know, moreover, that for 20 years search has been made for indubitable instances of transmission without success. When, therefore, the transmission is alleged I ask for proof. Dr. Wilson, in reply, refers me to the works of Darwin, Herbert Spencer, Eimer, and others-to this gentleman and that. He adopts an impossible method of controversy. I cannot review the works of Spencer, for instance, in the correspondence columns of THE LANCET. I am prepared, however, to make Dr. Wilson a reasonable offer. Let him describe (giving the necessary details) any instance of transmission alleged by the gentlemen he has named and I will undertake to demonstrate the fallacy. Incleed, so strong do I feel my position to be that I willingly grant him the whole literature of the subject to delve in.

The last sentence of his letter is characteristic. In effect he asserts that nobody has proved that acquired traits are not transmitted. I quite agree, and I may add that nobody will ever prove it, but only because no one can prove a negative. Suppose, for instance, I stated that at three minutes past midnight on Nov. 10th, 1900, a dragon sat and curled his whiskers on the cross of St. Paul's could anyone disprove the assertion? Could Dr. Wilson? Certainly not. He would merely say that my assertion was incredible and ask $m e$ for evidence. I ask him for evidence. 'The onus of proof rests with hirn.-I am, Sirs, yours faithfully,

Southsea, July 1st, 1901.

G. ARCHDALL REID.

\section{"PUERPERAL FEVER TREATED WITH ANTI-STREPTOCOCCIC SERUM."}

\section{To the Editors of THE LANCET.}

SIRs, -In The LArceT of June 29th, p. 1824, I read notes of a case which appears under the heading: "A Case of Puerperal Fever treated with Anti-streptococcic Serum; Death." I think this heading is distinctly misleading. From May 1st the patient is passing through an intensely septic process with repeated rigors, deliriun, incontinence of urine (which was albuminous), and thrombosis of both legs and left arm. The patient's condition became so critical that strychnine and brandy were necessary on May 18th. Then, on
May 19th, anti-streptococcic serum was used for the first time. I think that it would have been wise to have stated that the serum was first employed on the nineteenth day after the manifestation of septicæmia. Moreover, one would like to know whether: (1) the case had been proved to be one of pure streptococcic infection by bacteriological and microscopical examination; and (2) what was the nature of the nurse's infection? My personal experience of anti-streptococcic serum is that if it be used early and in sufficient dosage in suitable cases-i.e., in cases proved to be of streptococcic origin-it is as valuable a therapentic agent as anti-diphtheritic serum.

Bedford, June 30th, 1901.

S. J. Ross.

\section{ALFRED HUGHES MEMORIAL AT KING'S COLLEGE, LONDON.}

To the Editors of THE LANCET.

SIRs, - A movement has been set on foot to establish a memorial to the late Professor Hughes at King's College. It has been felt that his memory should be perpetuated in London as well as in Wales, for the last years of his life were spent with characteristic energy among London students. His anatomical collection has, in accordance with his expressed wish, been presented to King's College by Mrs. Hughes and will bear his name. It is hoped that the fund now being collected will enable us to erect a memorial tablet in the anatomical museum or college chapel and also to found a scholarship or medal in anatomy to be awarded annually and to be named after our late colleague. With this object in view a large number of circulars have been posted to members of the medical profession, prominent anatomists, and others. Already a considerable number of subscriptions have been sent in. These include $\& 5$ from Lord Lister, \&5 from the Hon. W. F. D. Smith, M.P. (treasurer of King's College), $£ 22 s$. from the Archbishop of York, and a number of others, principally from members of the Council, the staff, and the students of King's College. The object of this letter is to make the fund still more widely known. There are doubtless many of Professor Hughes's friends and old students whom it is difficult to reach in other ways who would like to show their appreciation of his worth by sending donations to the fund. A fulk list of subscribers will be published later. Contributions should be sent to me.

I am, Sirs, yours faithfully,

King's College, Strand, June 30th, 1901.

$$
\text { W. D. Halliburton. }
$$

\section{THE TREATMENT OF DYSENTERY AT SPA BY CHALYBEATE WATERS, \&c. To the Editors of THE LANCET.}

SIRS,-I think the following case of sufficient importance at the present juncture to warrant publication. Captain aged 27 years, good antecedents, consulted me at Spa on June 9th, having been invalided home from the Cape after dysentery. He had a relapse on the way home, and when first seen was passing from eight to ten bloody stools per diem, with inability to leave his hotel without previously taking 10 drops of chlorodyne, \&c. I put him on a course of our iron water and douches and an internal antiseptic treatment. The result has been most satisfactory. In 16 days he has put on eight pounds weight and is now, since eight days, passing formed stools without blood and has ceased using chlorodyne. I am, Sirs, yours faithfully,

Avenue du Marteau, Spa, June 28th, 1901. Dr. A. CafFerata.

\section{EQUINE VARIOLA-HORSE POX. To the Editors of THE LANCET.}

SIRs,-During the last few weeks I have had five or six cases of the above disease in the human being accidentally inoculated from the horse, but as $\mathrm{I}$ do not remember ever seeing any note of similar cases $I$ thought it might be of interest to record it. The subjects have all been stable lads employed at racing stables, and the disease bas generally been inoculated into the hand or arm while drenching or balling a horse. In one case, however, the upper eyelid was the seat of inoculation. The phenomena have been far more acute and of shorter duration than in vaccinia.

I am informed that several years ago a number of cases 
were seen here in which the symptoms were so acute that the disease was at first diagnosed as anthrax.

I am, Sirs, yours faithfully,

Newmarket, July 2nd, 1901. ERNEST CROMPTON, M.R.C.S.

\section{"SIMULATION OF BERI-BERI."}

\section{To the Editors of THE I.ANCET.}

SIRs,-Apropos of your annotation on simulation of beriberi in THE LANCET of May 25th, p. 1483, this method of producing an cedema of the feet is well known to Indian prisoners. I remember such an "outbreak" some years ago when it was found that the odema was produced by a needleand-thread soaked in lime.-I am, Sirs, yours faithfully, Bengal, June 9th, 1901.

W. J. B.

\section{THE DIFFERENCE BETWEEN THE GENERAL MEDICAL COUNCIL AND THE CONJOINT BOARD.}

\section{To the Editors of THE LANCET.}

Sins,-Having been forced to take great interest in the preliminary scientific education of medical students during the last two years my experiences and conclusions may interest your readers.

First, the experiences. In the autumn of 18991 applied at the offices of the General Medical Council for information as to where the first year of studentship might be passed, and was given the list of schools recognised by the Conjoint Board as being a reliable guide. In January, 1900, my eldest son, who had entered at one of these schools, was told when he applied to register that the list of the Conjoint Board was no longer recognised by the Council and that his case must be considered specially. Eventually, after a period of suspense, his time was recognised. In July, 1900, I wrote to the Registrar of the General Medical Council for a list of the schools recognised as another son had matriculated and I did not wish to send him to lodgings in London when he was barely 17. The Registrar wrote: "The question of the approval of these institutions is still under consideration, each case is meanwhile considered on its merits." The question remained under consideration for the whole of 1900, no doubt to the great inconvenience of many others besides myself and my son. I fixed on a public school recognised by the Conjoint Board which had four boys in its "science sixth," who had passed the Preliminary Scientific. London, and others preparing for it, and I inquired of the Registrar whether my second son's time would be recognised if it was spent there. His answer was to the effect that the Council objected to that class of school, but at the same time he recommended a university college in the same town at which my son would have none of the great advantages of school life-e.g., games, supervision, \&c. Eventually I had to enter him at a London hospital (paying $£ 50$ ) to enable him to register, and send him to an unrecognised school besides, as I wanted him to pass the Preliminary Scientific without unnecessary delay. If you inquire of students you will be astonished to find how many of the London hospitals cannot be relied upon to pass their candiclates for that examination. Some are safe on the zoological side but cannot teach students the necessary chemistry and physics; with others it is the opposite ; and probably there are some that can teach both, but the unrecognised school does best.

My conclusions are that the General Medical Council has not given due consideration to the convenience of medical students and their guardians. Full notice of these alteration should have been made public and sent to the schools concerned. (Two of the schools learned the news from me nine months after their tacit recognition by the Council had ceased.) The year and a half of suspense has probably been a great inconvenience to many and there should be strong grounds to excuse it. The final decision is likely to be very detrimental to students in future. Firstly, by preventing the youth of 16 or 17 years of age who is anxious to press forward in the medical profession from spending the usual final year at school where he learns much that is good for him as monitor, leader in games, and such like, to say nothing of the great physical adrantages which school has over life in London lodgings. These deprivations I regard as positively cruel towards the student and injurious to our profession, which depends on the good qualities of its nembers for the position which it holks. If the rising generation of medical practitioners be forcel into cheap lodgings in big cities at an early age we may safely foretell retrogression. Secondly, in many cases the youth will have to forego a good system of edication for an inferior one.

The Conjoint Board may have been too free with its recomitions, but certainly the Council has not been free enough. Surely all schools which can pass students for the Preliminary Scientific, London, regularly might be recognised by the Council, or, better still, students who pass the preliminary scientific or first professional examination of any licensing body might be accredited with having done the period of studentship allotted to preparation for it by medical schools. Why should a system of protection through registration be afforded to the recognised medical schools and a few others when their education in elementary science. is not always the best. There is a general opinion that the great argument in favour of the five years' curriculum. was that medical students had not enough practical work: in their courses and that part of the fifth year at least was to. be devoted to assisting physicians, surgeons, or general practitioners in hospital or outside. Now that it is instituted we find students forced to spend at least a year at preliminary subjects and the same old want of real. experience facing the newly-fledged licentiate though he bas spent more time and more money in getting qualified than his father did (for all the hospitals have raised their fees). May the memory that, unlike his father, he spent much time. and energy in hunting for the ovaries of earth-worms and the. lymphatic hearts of frogs console him in his trouble over failure to put his first good private patient on a satisfactory. diet. Is this elaborate training in elementary science really advisable? It is possible to give students too much of a good thing. June 28th, 1901. I am, Sirs, yours faithfully,

MEDICUS ET PATER.

\section{BIRMINGHAM}

(FroM OUR OWN CORRESPONDENT.)

\section{Birmingham and Midland Counties Branch of the British Medical Association.}

THE annual meeting of the Birmingham and Midland Counties Branch of the British Medical Association was. held on June 13th at the Medical Institute. The report of the council stated that the last year had been one of exceptional interest and activity. In addition to the ordinary meetings two special meetings of the branch had been held, and the attendance had reached the high average of 65 per meeting, the extremes being 38 and 109 . There had also been six special council meetings. One of the special branch meetings and the greater part of one ordinary meeting were devoted to a discussion on the Coventry Provident Dispensary, and a resolution was passed expressing the opinion that no professional recognition should be given to the medical staff of that institution by members of the branch. Forty new members had been elected during the session, and the present membership of the branch was 443 . The report of the pathological and clinical section, and the report of the ethical committee were received, both of which evinced signs of much valuable work during the session. The financial report showed a balance of $£ 234 s$. Various votes of thanks were passed. Dr. Malins was elected president and Mr. J. T. J. Morrison and Dr. T. Stacey Wilson were elected honorary secretaries. The members, with a distinguished representation of the City Council, the University, and friends, dined together subsequently, the proceedings being characterised by enthusiasm and good feeling throughout.

\section{The University of Birmingham.}

The different faculties have had a busy time recently in conducting examinations for degrees of the new University. The medical faculty has been exceptionally occupied by the large number of candidates. Forty-one qualified medical men availed themselves of the opportunity of taking the final examination for the degrees of M.B. and Ch.B., having been past students of the school. Some 27 of these were successful. The first degree congregation of the University is to be held in the Town Hall on July 6th when the Chancellor of the University, the Right Hon. Joseph Chamberlain, will confer degrees upon the 